\title{
The Progressive Muscle Relaxation and Deep Breathing as Effective Procedures in Reducing the Stress Levels on Older People
}

\author{
Rizky Erwanto ${ }^{1}$, Fajarina Lathu Asmarani ${ }^{2}$ \\ ${ }^{1}$ Program Pendidikan Profesi Ners Universitas Respati Yogyakarta \\ ${ }^{2}$ Program Pendidikan Profesi Ners Universitas Respati Yogyakarta \\ Email : rizkyerwanto@gmail.com
}

\begin{abstract}
Abstrak
Jumlah dan proporsi lansia di dunia saat ini mengalami peningkatan. Seiring dengan peningkatan jumlah lansia tersebut perlu mendapat perhatian dikarenakan lansia termasuk kelompok/populasi beresiko (population at risk). Populasi berisiko merupakan kelompok yang mempunyai karakteristik tertentu yang dapat menimbulkan masalah kesehatan. Perubahan kemampuan fisik dapat mempengaruhi fungsi dan kemampuan tubuh secara keseluruhan. Salah satu perubahan yang terjadi pada proses penuaan yaitu perubahan psikososial. Perubahan psikososial juga mengakibatkan stres pada lansia. Salah satu penatalaksanaan keperawatan komplementer dan alternatif.adalah dengan terapi relaksasi otot progresif dan nafas dalam. Relaksasi otot progresif dan nafas dalam tidak menimbulkan efek samping, tidak membutuhkan biaya, dapat dilakukan secara mandiri, dan tidak memerlukan pelatihan rutin dari instruktur, menurunkan denyut jantung serta membuat tubuh menjadi rileks. Intervensi ini dapat dilakukan oleh perawat maupun care giver di layanan institusi atau panti wredha yang dilaksanakan sesuai dengan SOP (Standart Operasional Prosedure). Penelitian ini bertujuan untuk mengetahui keefektifan relaksasi otot progresif dan nafas dalam untuk menurunkan stres pada lansia di Panti Wredha Hanna Yogyakarta. Populasi lansia di Panti Wredha Hanna sebanyak 40 lansia. Penelitian ini menggunakan metode Quasy experimental menggunakan rancangan pre dan post without control group design Teknik pengambilan sampel dengan menggunakan quota sampling yang memperhatikan kriteria inklusi maupun ekslusi. Peneliti menggunakan istrumen DASS untuk mengukur stres lansia. Hasil pengukuran fungsi stres lansia dengan menggunakan DASS, terdapat penurunan nilai mean sebesar 4,4 point. Uji paired t-test didapatkan p-value 0,000. Hasil uji bivariate menggunakan instrument DASS menunjukkan bahwa intervensi relaksasi otot progresif dan nafas efektif menurunkan stres pada lansia di Panti Wredha Hanna Yogyakarta.
\end{abstract}

Kata kunci: relaksasi otot progresif, nafas dalam, stres, lansia

The world population and proportion of elderly people at present are increasing. The increasing population of the elderly people needs special attention because elderly people included in the group of a population at risk. A population at risk is the group with certain characteristics that able to generate health issues. The changes in physical capability are able to influence the entire body's functions and capabilities. One of the occurring changes is the aging process embodied as psychosocial changes. The psychosocial changes also able to induce a stress in elderly people. One of the complementary and alternative nursing management is through the therapies of a progressive muscle relaxation and a deep breathing. Progressive muscle relaxation and deep breathing do not cause side effects, do not require additional cost, and can be performed individually as well as do not require routine training from the instructor, able to reduce the heart rate and able to relax the body. 
These interventions can be done by nurses or caregivers in service institutions or nursing home which performed in accordance with the determined SOP (Standard Operational Procedure). This research is aimed to determine the effectiveness of progressive muscle relaxation and deep breathing to reduce the stress on elderly people in the Hanna Nursing Home Yogyakarta. There were 40 elderly people who live in Hanna Nursing Home involved in this study. This research method was a Quasi Experimental design with pre and post test without control group design. The sample tehcnique in this study was quota sampling which considers either inclusive or exclusive criteria. The instrument of the study was DASS instrument to measure the stress levels of elderly people. The measurement results of the stress function of elderly people through the utilization of DASS show that there was a decline of mean value in about 4.4 points. From the paired t-test, $0.000 p$-values were acquired. The results of the bivariate test by using the DASS instrument showed that the interventions of progressive muscle relaxation and deep breathing in reducing the stress of elderly people in Hanna Nursing Home Yogyakarta were effective.

Keywords: the progressive muscle relaxation, deep breathing, stress, elderly people.

Article info:

Article submitted on July 11, 2017

Articles revised on August 15, 2017

Articles received on September 29, 2017

DOI: http://dx.doi.org/10.21927/jnki.2018.6(1).42-48

\section{INTRODUCTION}

The world population and proportion of elderly people at present are increasing. United Nations Department of Economic and Social Affairs/Population Division (2015) mentioned that in 2015 , the population of elderly people in the world are 901 million people with $12.3 \%$ of the entire populations. The $>60$ years old population has experienced $3.26 \%$ growth every year. Indonesia is a country with $8.9 \%$ of elderly people population in the world (1). The 2013 - population of elderly people in Indonesia is $8.9 \%$, it is predicted that in 2015; the number will increase to $21.4 \%$ and in 2100 will grow into $41 \%$ (2). The results of population projection in the 20102035 period are indicating that Indonesia has entered the aging era, it is predicted that there will be $10 \%$ of $>60$ years old population in 2020 (2). Yogyakarta Special Province (DIY) is the region with the highest elderly people population in Indonesia which amounted to $13.4 \%$ (2). The province with the highest proportion of elderly people in Yogyakarta Special Province (14.02\%)
(3). These conditions have made the Yogyakarta Special Province to be included as the region that enters the era of the aging structured population due to the population of $>60$ years old which has exceeded 7 percent rate.

Along with the increasing population of the elderly people, thus, a special attention is required because elderly people are included in the group of a population at risk. A population at risk is the group with certain characteristics that able to generate health issues. Elderly people as the population at risk are conceived with biological characteristics and age, social, economy, lifestyle, and life events (4). Elderly people are also defined as the vulnerable population because they attached by characteristics that have more possibilities to generate health issues, find more difficulties in accessing the health service to overcome the health issues, decreasing rate of income or shorter live expectancy due to health conditions (5). Elderly people are highly associated with various changes due to the aging processes, including the change of anatomy of 
physiology, disease, pathologic as the result of aging, and the psychosocial impacts on organ functions (6).

Psychosocial changes also generate stress on elderly people, for example when the elderly people are started to retire. Retired is frequently miss-understood by elderly people as the forms of passiveness and abandonment in which the transition of the role is occurring (7). The data collected from Basic Research of Health in 2013 showed that the elderly people who experience health issue of the emotional mental disorder have reached $8.34 \%$ at the age of $55-64$ years old, $10.0 \%$ at the age of $65-74$ years old, and $12.5 \%$ at $>75$ years old. The number of the event for women is higher, which reached $8.9 \%$ compared to men which reached $5.0 \%$ (8). Barun et al (2011) in the research conducted by Anisya (2016) mentioned that the prevalence of old age people who experienced stress in the world is 4.7-16\%.

The mental health disorders, such as depression and anxiety will increase the risk of stress occurs in elderly people (9). A stress generates stimulation on someone in terms of achieving a stage of change in his/her life. The high amount of stress will induce negative feelings, disruption in reaching a reality, unable to solve the problem in life, and even generate an impact towards health conditions on every system exist in the human body (7). Hawari (2011) mentioned that someone who experienced a stress will lead to a depressing condition if not being handled properly. Priyoto (2014) mentioned that the impacts of stress are divided into three categories, namely the physiologic impacts such as experiencing several physical symptoms, psychological impact such as fatigue, emotion, boredom, burn-out event, decreasing achievement, and behavioral impacts such as attitudes that unacceptable for the society and the abilities of remembering information and making decision. The stress levels are able to discover through DASS 42 measurement/assessment. Akin \& Cetin (2007) stated that the validity and reliability values on DASS scales have an adequate high value. The DASS questionnaire can be used as an effective instrument in assessing the emotional condition; therefore, the DASS 42 questionnaire is a valid and reliable instrument to assess the emotional condition (10).

The Indonesian Law No.36/2006 regarding Health is stating that the medical effort for elderly people should be aimed to maintain a healthy and productive life in social or economic manner by referring to human dignity. The government should ensure the availability of health facilities and also facilitate the old age group to live independently and productive in social and economic manners. In the Indonesia Law No.38/2014 regarding nursery on Article 30 , it is mentioned that in performing the duty of nursery in public health sector, one of the nurse responsibilities is conducting the complementary and alternative nursery management.

One of the complementary and alternative nursery management is through progressive muscle relaxation and deep breathing. The progressive muscle relaxation and deep breathing do not cause side effects, do not require additional cost, and can be performed individually as well as do not require routine training from the instructor, able to reduce the heart rate and able to relax the body (11). According to the interview results towards 10 elderly people in Hanna Nursing Home Yogyakarta, it is acquired that 7 of 10 elderly people have experienced sleep difficulties, frequently being awake at night due to certain thoughts but being uncertain of what kind of those thoughts are, uncomfortable feeling but not aware of the causes, felt pressured, and homesick. The elderly people express that to reduce their anxiety; they usually conduct some conversations with their friends. The interventions that have been conducted in Hanna Nursing 
Home are aiming to reduce the stress by inviting the elderly people to have collective vacation and spiritual activity. The interventions of progressive muscle relaxation and deep breathing are never been conducted before in Hanna Nursing Home. This method is developed by combining two interventions such as the progressive muscle relaxation and deep breathing which expected to be able to reduce the blood pressure of elderly people in Hanna Nursing Home Yogyakarta.

\section{MATERIALS AND METHOD}

This research was quantitative research using the Quasi-experimental study. This research was pre and post without control group design to determine the effectiveness of progressive muscle relaxation and deep breathing towards the stress levels of elderly people. The population of this research was 40 elderly people who live in Hanna Nursing Home - Yogyakarta. The criteria of research sample were the $>60$ years old elderly people, willingly become the research subject by using informed consent, present during the research implementation, the elderly people who have a mental disorder, the elderly people who have joints movement disorder and post-stroke. The sampling technique was quota sampling by consistently referring to the research sample criteria which resulted in 20 elderly people. The bivariate test used in this study was paired t-test because distributed normally through the utilization of DASS instrument.

\section{RESULTS AND DISCUSSION}

The characteristics of respondent include the age and stress levels of elderly people in Hanna Nursing Home Yogyakarta.

According to Table 1, the characteristic of elderly people age was mostly categorized in very old age people who amounted to 15 people (75\%). The elderly people who experience a stress before the interventions of progressive
Table 1. Respondent Characteristics in Accordance with the Age and Stress Levels (Pre and Post) of Elderly People in Hanna Nursing Home Yogyakarta $(n=20)$ in Mei 2017

\begin{tabular}{lcc}
\hline Respondent Characteristics & f & $\%$ \\
\hline Age & & \\
$\quad$ Elderly (60-74 years) & 5 & 25.0 \\
$\quad$ Old (> 75 years) & 15 & 75.0 \\
Stress-Pre & & \\
$\quad$ Normal & 6 & 30.0 \\
$\quad$ Mild & 7 & 35.0 \\
$\quad$ Moderate & 7 & 35.0 \\
Stres Post & & \\
$\quad$ Normal & 11 & 55.0 \\
$\quad$ Mild & 7 & 35.0 \\
$\quad$ Moderate & 2 & 10.0 \\
Total & 20 & 100 \\
\hline
\end{tabular}

muscle relaxation and deep breathing were more than half categorized in light and medium stress that amounted to 7 respondents (35\%), most of the elderly people were categorized in the normal condition which amounted to 11 respondents (55\%). According to Miller (2012), there are several factors that influence the stress on elderly people, including the loss of life-partner, loss of a friend, pension, chronic disease, away from their families, and wrong perception about old age. These conditions occurred in some elderly people in the nursing home because all the elderly people are far from their families and some of them are already left by their lifepartners. According to Indriana, Kristiana, Sonda, Intanirian (2010), the 5 major factors that produce stress on elderly people in nursing home are the change in daily activities, the change in family gathering, the death of life-partner, the death of family members, and the change in selecting the determining the quantity of sports or vacation, and the change in occupation.

According to Table 2, the stress scores (Pre and Post) decrease from the average 16.10 into 11.70 after the interventions of Progressive Muscle Relaxation and Deep Breathing, as also occurred on the median values which having a decrease from 17.5 to 13 after the interventions are provided. 
Table 2. Respondent Characteristics in Accordance with the Stress Scores (Pre and Post) in Hanna Nursing Home Yogyakarta $(n=20)$ in Mei 2017.

\begin{tabular}{lcc}
\hline $\begin{array}{c}\text { Respondent } \\
\text { Characteristics }\end{array}$ & $\begin{array}{c}\text { Stress Score } \\
\text { (pre test) }\end{array}$ & $\begin{array}{c}\text { Stress Score } \\
\text { (post test) }\end{array}$ \\
\hline $\mathrm{N}$ & 20 & 20 \\
Mean & 16.10 & 11.70 \\
Median & 17.50 & 13 \\
Min & 2 & 1 \\
Max & 25 & 22 \\
Standart Deviation & 6.553 & 6.258 \\
\hline
\end{tabular}

Table 3. The stress levels of respondents in before and after the interventions

\begin{tabular}{lccc}
\hline \multirow{2}{*}{ Paired t-test } & \multicolumn{2}{c}{ Mean } & \multirow{2}{*}{$p$-value } \\
\cline { 2 - 3 } & Pre & Post & \\
\hline Stress score & 16.10 & 11.70 & 0.000 \\
\hline
\end{tabular}

In order to discover the data normality, thus, the researcher was the Shapiro-Wilk test, because the respondents are less than 50 people. The results of normality test of stress score before the interventions were performed is 0.121 and the stress score after the interventions were performed is 0.253 which show that the data was distributed normally because they have more than 0.05 values. The bivariate test was paired t-test because it distributed normally. There were the differences of mean values by 4.4 points. The results of hypothesis test resulted in $0.000 p$ values which mean that there was a significant difference in stress scores in before and after the interventions of progressive muscle relaxation and deep breathing are conducted.

According to the analysis of stress scores data of elderly people in before the interventions were conducted, most of the elderly people are having light and medium stress, which amounted to $35 \%$. The mean value of stress scores on elderly people is 16.10 which categorized as light stress. According to the interview results with the elderly people, the reasons of the stress experienced by the elderly people are because they frequently being awake at night due to certain thoughts but being uncertain of what kind of those thoughts are, uncomfortable feeling but not aware of the causes, felt pressured, and homesick. Elderly people are the vulnerable population, the vulnerability can be caused by the physical limitations and the causes sourced from environmental conditions, the personal source (human capital), and the bio-psychosocial sources (diseases and genetic tendencies) (4). Stress is the response of someone towards the demands that able to put them in a tense situation, influencing the emotion and health condition of someone (12). The main sources of the stressor on elderly people include the normal aging process that disrupts the physical function, the activities, change of look, social loss, environment, change of role, and the death of the most-loved person (9). The psychosocial change also causes the stress on elderly people (7).

According to the data analysis of the stress scores of elderly people, after the interventions were conducted, the stress levels of elderly people are mostly categorized in a normal condition which amounted to $55 \%$. The mean value of stress scores on elderly people is 11.70 which included in the normal category. There is an increase of the mean value of stress scores by 4.4 points. In category, the average stress levels of elderly people are also changed that before categorized in light and medium stress which now changed into experience non-stress condition. The interventions conducted by the researcher were in accordance with the theory regarding progressive muscle relaxation which mentions that the relaxation is one of the techniques in the therapy of behavior performed on someone during the tense and relaxed condition. In the time when body and mind are relaxed, the muscle tension is having a relaxation (13). The relaxation techniques that frequently used are muscle relaxation, relaxation with guided imagery, and the relaxation response of Benson. The aim of relaxation practice is to produce a response that able to fight a stress response. If the aim is achieved, thus, the hypothalamus activity will adjust and the declining 
activities of sympathetic and parasympathetic neuron systems will occur. The sequence of physiological effect and the symptoms or the signs will break and the psychological stress will decrease (9). Relaxation is aimed to decrease sympathetic neuron system, increase the activity of parasympathetic, decrease the metabolism, decrease blood pressure and heart rate as well as to decrease the oxygen consumption. Relaxation might provide a contrast activity with the continuous negative effects of the chronic stress. The progressive muscle relaxation is a method to facilitate a reduction of tension, thus, the body muscles will relax. The progressive muscle relaxation is aimed to reduce anxiety, stress, tensed muscled, and sleeping difficulties (7). These conditions are in accordance with the research conducted by Magfirah, Sudiana, and Widyawati (2015) which mentioned that there are impacts resulted from progressive muscle relaxation towards the decreasing level of psychological stress on DM type-2 patients.

During the activity of progressive muscle relaxation, the elderly people also perform deep breathing. Deep breathing or diaphragm breathing is a relaxation technique by maximally expanding the diaphragm, thus, the oxygen will be able to enter the entire parts of the body. The deep breathing is aimed to be able to breathe slowly and to lower the shoulder, neck, and upper chest muscle, thus, the breathing process will be more efficient (14). Breathing relaxation therapy is the breathing process through an abdomen in slow or gradual frequency, rhythmic, and comfortably performed in eyes-closed condition (15). The breathing is performed by requesting the client to inhale through the nose as deep as possible then hold it for three seconds or in three counts then exhale it through the mouth with wrinkled lips like performing a whistle (16).

According to Godbout et al (2011), the Deep Breathing Exercise is effective in preventing stress in elderly people who have strokes.
Deep breathing exercise is useful to reduce the stress levels that occur in stroke patients, thus, the risk of stroke or recurrent stroke is able to be reduced. The relaxation technique is able to stimulate several body responses, including the decreasing of heart rate, the decreasing level of blood pressure, the decreasing rate of breathing, and the decreasing muscle tension. Performing deep breathing for 20-30 minutes every day will reduce anxiety and stress. Deep breathing exercise is able to increase the supply of oxygen to the brain and stimulate the parasympathetic nervous system, thus, someone will become calm and relaxed (17). These conditions are also in accordance with the research conducted by Patil \& Bhupali (2016) which mentioned that the breathing exercises as non-pharmacological, non-invasive and affordable relaxation techniques are able to reduce the stress levels in patients who underwent the intradialytic treatment.

\section{CONCLUSION}

The age of respondents was mostly categorized in the old age category. The elderly people stress levels in before the interventions were mostly categorized in light and medium stress. The stress levels of elderly people in after the interventions were mostly categorized in the normal category. The implementations of progressive muscle relaxation and deep breathing interventions were effective in reducing the stress of elderly people.

\section{SUGGESTION}

According to the research that has been conducted, the suggestions are as follows:

a. For the Head of Hanna Nursing Home Yogyakarta

To develop the Standard Operational Procedure (SOP) regarding the progressive muscle relaxation and deep breathing to be used as one of the nursery interventions to reduce the stress on elderly people. 
b. Elderly People

To perform the progressive muscle relaxation and deep breathing in routine behavior for 15 minutes every day to reduce stress.

\section{REFERENCES}

1. United Nations Department of Economic and Social Affairs/ Population Division. Word Population Prospects Key Finding and Advance Tables. United Nation New York;2015

2. Information and Data of Indonesian Health Ministry. Situasi Lanjut Usia (LANSIA) di Indonesia. Jakarta; 2016

3. National Commission of Elderly People. Pengenalan Gerontologi dan Geriatri bagi Masyarakat. Jakarta : Komisi Nasional Lanjut Usia; 2011.

4. Stanhope, M. \& Lancaster, J. Community \& public health nursing (six ed.). St. Louis, Missouri: Mosby; 2004

5. Maurer, F. A., \& Smith, C. M. Community/ Public

6. Health Nursing Practice: Health for Families and Populations. Philadelphia: Elsevier Saunders; 2005

7. Darmojo, B. Buku Ajar Geriatic (IImu Kesehatan Lanjut Usia) edisi ke - 4.Jakarta : FKUI; 2011

8. Potter \& Perry. Fundamental Keperawatan. Jakarta : EGC; 2005

9. Basic Research of Health. Riset Kesehatan Dasar 2013. Kementerian kesehatan.2013

10. Smeltzer, S,C \& Bare, B,G. Medical - Surgical Nursing. Wolters Kluwer Health; 2010

11. Lovibond. Depression Anxiety Stress Scale 42 (DASS 42), (online), (http://www2.psy.unsw. edu.au/groups/dass/Indonesian/Damanik.htm); 1995

12. Muttaqin, A. Asuhan Keperawatan Klien dengan Gangguan Sistem Pernapasan . Jakarta : Salemba Medik; 2014

13. Lukaningsih, Z, L \& Bandiyah, S. Psikologi Kesehatan. Yogyakarta. Nuha Medika; 2011
14. Ramdhani, N., \& Putra, A. A. (2009). Pengembangan multimedia relaksasi. Jurnal Psikologi Volume 34 no.2. Diakses 6 Juni (2018) dari http://www.pzikologizone.com/ langka h-langkah-relaksasi-otot-progresif

15. Lindquist, R., Snyder, M \& Tracy, M.F. (2014). Complementary \& Alternative

16. Marksberry, K. (2012). Take a Deep Breath. The American Institute of Stress. https://www. stress.org/take-a-deep-breath/

17. Akin, A. \& Cetin, B.The depression anxiety and stress scale (DASS): The study of validity and reliability. Kuram Ve Uygulamada Egitim Bilimleri, 7 (1),260-268.2007. http://search. proquest.com/docview/236995712?accounti d=25704 Diakses pada 17 Januari 2017.

18. Anisya, A. Hubungan Stress Dengan Kejadian Insomnia pada Lansia di Panti Sosial Sahai Nam Aluih Sincin. Universitas Andalas; 2016

19. Hawari, D. Manajemen Stress, Cemas, dan Depresi edisi ke-2. Jakarta : FKUI; 2011

20. Indriana, Y., Kristiana, I.F., Sonda, A.A \& Intanirian, A,. Tingkat Stres Lansia Di Panti Wredha "Pucang Gading" Semarang Jurnal Psikologi Undip Vol. 8, No. 2, Oktober 2010

21. Magfirah, S., Sudiana, I.K., \& Widyawati, I.Y. Relaksasi Otot Progresif Terhadap Stres Psikologis dan Perilaku Perawatan Diri Pasien Diabetes Mellitus Tipe 2. Jurnnal Kesehatan Masyarakat. KEMAS 10 (2) (2015) 137-146

22. Miller, C. A. Nursing for Wellness in Older Adults: Theory and Practice. Sixth Edition. Philadelphia: J.B Lippincott Company; 2012 23. Patil, R. R \& Bhupali, P.R. Effectiveness of Deep Breathing Exercise to Reduce Stress among Intradialytic Patients Admitted in Tertiary Care Hospital, Belagavi, Karnatak. International Journal of Cardiovascular Nursing Vol. 1: Issue 2, 2016

24. Priyoto. Konsep Manajemen Stres. Yogyakarta. Nuha Medika; 2014 